\title{
Neck and shoulder pain among elementary school students: prevalence and its risk factors
}

Elham Gheysvandi ${ }^{1}$, Iman Dianat ${ }^{2}$, Rashid Heidarimoghadam ${ }^{3,4}$, Leili Tapak ${ }^{5,6}$, Akram Karimi-Shahanjarini ${ }^{1,7}$ and Forouzan Rezapur-Shahkolai ${ }^{1,4,7^{*}}$

\begin{abstract}
Background: Neck and shoulder pain is relatively common among children and teenagers and has a negative impact on their physical and psychological health. This study was carried out to assess the prevalence of neck and shoulder pain among elementary school students, and to investigate the relationship between this pain and its risk factors.

Methods: In this cross-sectional study, 693 elementary school students aged 7 to 12 years from Hamadan city, located in western Iran, were selected through the multistage cluster random sampling method. Data were collected through interviews and questionnaires. For the social and psychological variables, the parent version of the Strengths and Difficulties Questionnaire (SDQ) was used. For assessing each student's posture, an observational checklist, the Rapid Upper Limbs Assessment (RULA), was used. The data was analyzed using the unadjusted (univariate) and adjusted (multivariate) logistic regression.
\end{abstract}

Results: The prevalence of the neck pain was slightly higher than that of shoulder pain. The prevalence reported over a month was 35.8 and 30.9\% for neck and shoulder pain, respectively. The logistic regression analyses showed that, very high desk height (odds ratio $(\mathrm{OR})=1.96,95 \%$ confidence interval $\mathrm{Cl}$ : 1.02-3.74), backward seat pan inclination (OR=2.10, $95 \% \mathrm{Cl}: 1.37-3.24)$, forward seat pan inclination $(\mathrm{OR}=3.12,95 \% \mathrm{Cl}: 1.46-6.68)$, difficulty in viewing the board $(\mathrm{OR}=2.54$, 95\% Cl: 1.10-5.84), too much homework (OR=2.59, 95\% Cl: 1.49-4.51), RULA score at level III (OR=2.88, 95\% Cl:1.64-5.05), and RULA score at level IV (OR $=3.12,95 \% \mathrm{Cl}: 1.72-5.63)$ increased the risk of neck pain independently. On the other hand, sitting on desk and seat ( $\mathrm{OR}=0.59,95 \% \mathrm{Cl}$ : 0.39-0.91) and laying position for doing homework $(\mathrm{OR}=0.53,95 \% \mathrm{Cl}$ : $0.34-0.81)$ reduced the related risk. Very short desk height $(\mathrm{OR}=2.41,95 \% \mathrm{Cl}: 1.26-4.61)$ and too much homework $(\mathrm{OR}=$ $1.94,95 \% \mathrm{Cl}: 1.10-3.42)$ increased the risk of shoulder pain.

Conclusion: The elementary school students reported a high prevalence of shoulder and neck pain. This study found that improper sitting positions, as well as physical factors such as the school furniture, too much homework, and difficulty in viewing the classroom board, were associated with pain. Proper interventions considering the risk factors assessed in this study, are suggested.

Keywords: Musculoskeletal complaints, Children, Adolescent, Physical risk factors, Psychological risk factors; Posture.

\footnotetext{
* Correspondence: forouzan.rezapour@gmail.com

${ }^{1}$ Department of Public Health, School of Public Health, Hamadan University

of Medical Sciences, Hamadan, Iran

${ }^{4}$ Research Center for Health Sciences, Hamadan University of Medical

Sciences, Hamadan, Iran

Full list of author information is available at the end of the article
}

(c) The Author(s). 2019 Open Access This article is distributed under the terms of the Creative Commons Attribution 4.0 International License (http://creativecommons.org/licenses/by/4.0/), which permits unrestricted use, distribution, and reproduction in any medium, provided you give appropriate credit to the original author(s) and the source, provide a link to the Creative Commons license, and indicate if changes were made. The Creative Commons Public Domain Dedication waiver (http://creativecommons.org/publicdomain/zero/1.0/) applies to the data made available in this article, unless otherwise stated. 


\section{Background}

Neck and shoulder pain is a relatively mild musculoskeletal condition [1], but in recent years it has become a major health problem, and has imposed a heavy burden on the person and community [2-4]. The World Health Organization (WHO) has ranked neck pain and other musculoskeletal diseases as the fourth and tenth health problems, respectively, for years lived with disability [5]. The Data show that, the prevalence of neck pain in the general population ranges from 0.4 to $86.8 \%$ in the world [6]. In addition, the Global Burden of Disease Study showed that neck pain is one of the main causes of years lived with disability among adolescents aged 15 to 19 . Compared to the other health problems such as asthma, alcohol and drug abuse it has a higher prevalence [7]. Also some studies indicate that shoulder and neck pain is more common among children and teenagers of developing countries [8-10]. For example, in Iran, neck or shoulder pain was reported $28.6 \%$ among 11-14-year-old children [11]. Lifestyle, physical factors, psychological factors, and social factors and improper sitting have been identified as the risk factors associated with neck and shoulder pain among students in different studies [3, 12-17]. Furthermore, neck and shoulder pain among children is considered as a risk factor for health problems during adulthood [18, 19]. Therefore, detecting and understanding the pain and managing it during childhood and adolescence is needed to prevent such problems. Given the importance of healthier body composition in childhood which is closely related to healthier profile in adulthood later, it is absolutely essential to identify the risk factors which are major contributors to health problems among children [20]. However, the results on the risk factors (e.g. physical and leisure activity, psychosocial variables, and school-related factors such as classroom furniture) and their relationship to neck and shoulder pain among children and teenagers are not consistent in different studies [21-25]. In additon, the number of the studies which consider all the above mentioned factors is limited. Moreover, little research has focused on the prevalence and the risk factors associated with shoulder and neck pain among the students in elementary schools $[9,11]$. Therefore, this study seeks to assess the prevalence of shoulder and neck pain and its potential risk factors among elementary school students.

\section{Methods}

The participants in this cross-sectional study were 693 elementary school students (318 boys and 375 girls), and their parents. They were all from Hamadan, a city located in the west of Iran. Students were in grades 1-6 (7 to 12 years old). Data was collected from 20 January to 17 March 2018. The sample size was estimated by using the $n=\frac{(\approx a / 2)^{2} p(1-p)}{E^{2}}$ formula, taking into account the
95\% confidence level, $0.95(1-\alpha=0.95)$, the same prevalence that Dianat et al. found in their study [11], with a $p=0.28$ and an estimation error (E) of maximum $15 \% \mathrm{p}$ and applying a cluster sampling factor of 1.5. Therefore the sample size was estimated as 670 students. A random sampling method with a multistage design was used in this study. Hamadan has two educational districts which were considered for sampling. At the first step, the list of elementary schools was prepared and then schools from districts 1 and 2 with high, moderate and low socioeconomic statuses were chosen. Accordingly, 13 schools from the mentioned districts (six from district 1 and 7 from district 2) in terms of gender classifications (male/female) were chosen, as schools in Iran are not coeducational, girls and boys study in single-sex schools. In each school, one classroom from each grade, and then from each classroom, a number of students were chosen through the simple random sampling method based on the sample size (Fig. 1). Finally, the students were selected according to the following criteria for inclusion: (1) being a student in elementary school, and (2) not having chronic diseases or musculoskeletal constraints. The exclusion criteria included not having consent to participate in the study (students and/or their parents).

Prior to collecting data, permissions were received from Education office authorities to collect data in the schools, and the students were informed that the participation in the study was voluntary. Oral informed consents from the students and the written informed consents from students' parents were obtained. There were 780 eligible individuals, of which 693 participated in the study (participation rate $=88.8 \%$ ).

For the questions about demographic variables, physical activity / leisure time and school related variables, Dianat et al. and Hatami et al., questionnaires (in Persian) were used. These questionnaires have been shown to be adequately reliable and valid $[11,26]$. Minor revisions were made according to the experts' opinions to adapt the items of the questionnaires for the study population in the present study. The questionnaires were tested in a pilot study on 60 students. According to their comments, partial revisions were made to a number of items in the questionnaire to improve transparency and understandability. Additionally, the test-retest approach was used to assess the reliability of the questionnaire items using the Kappa Coefficient (ranging from 0.73 to 0.95) and Internal Correlation Coefficient (ranging from 0.85 to 0.98 ). The questionnaire developed consisted of three parts. The first part was about the demographic variables and physical activity/leisure time (including age, gender, school grade, physical activity, using of cell phone, using of computer, computer games, and watching television). The second part focused on the school 


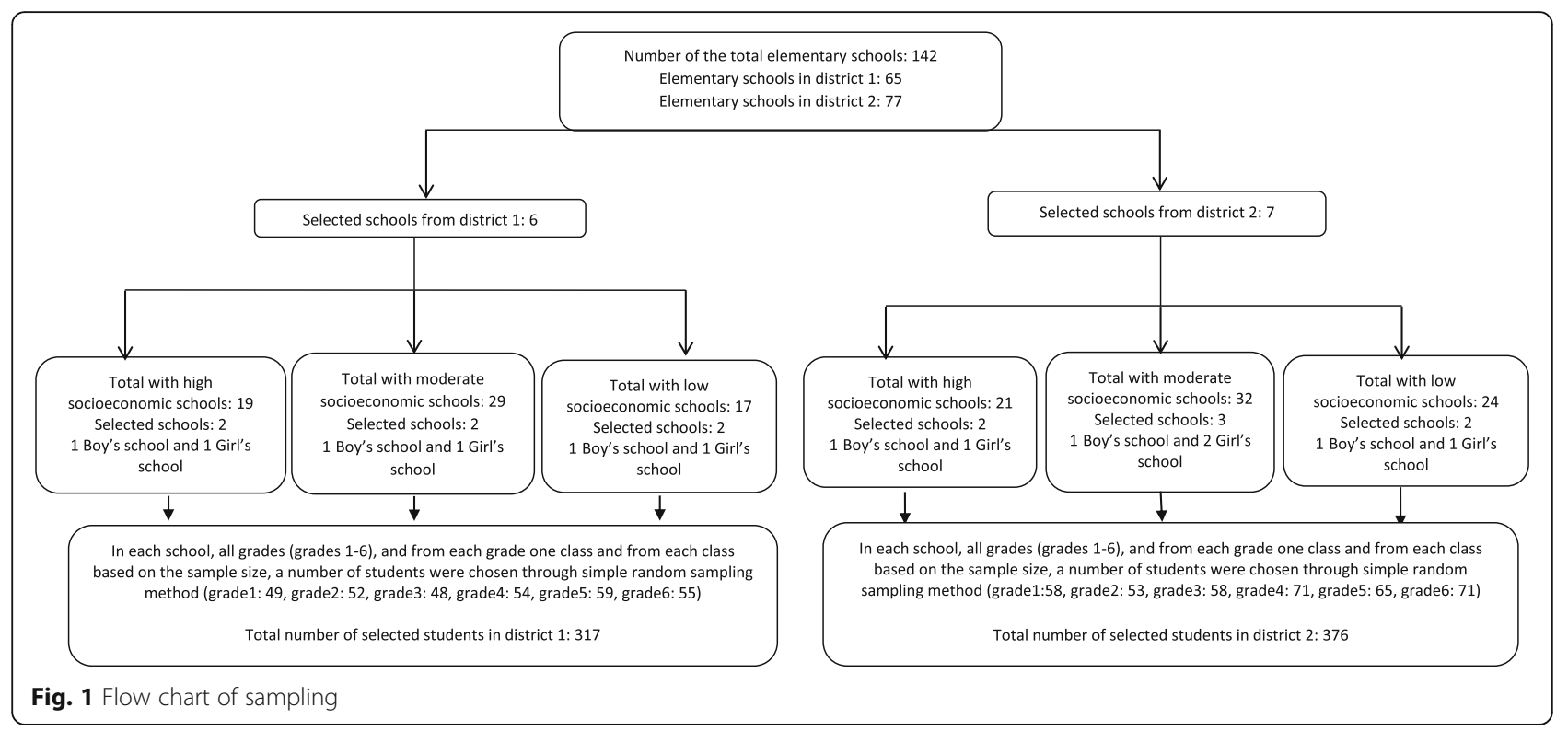

associated factors and information about the suitability and comfort of the school furniture (based on a modification of the Chair Feature Checklist), and the design of the classroom and amount of homework. The last part of the questionnaire included questions about the type of school backpack, how students carry backpack to school and the duration of backpack carrying to school.

To evaluate the students' posture, the Rapid Upper Limbs Assessment (RULA) checklist was used. RULA which had been developed as an observational method for investigating improper postures among workers was used in this study. First, observations were recorded as numerical scores, then these scores were converted to the final scores through the RULA specific matrix scoring, so that higher scores represented improper postures. The classification of scores was as follow: Level 1: a score of one or two which indicates that the posture is acceptable if not maintained for a long period of time. Level 2: a score of three or four which indicates that further investigation is needed and changes may be required. Level 3: a score of five or six which indicates that the investigation is needed and changes are required, soon. Level 4: a score of seven or more which indicates that further investigation and immediate changes are required [27]. The validity of the RULA checklist in Iran was previously examined by Dianat and Salimi [28] whereas, its reliability was assessed, through inter-rater reliability, at two different times, using a pilot study on 60 students in the current study. The Cronbach's alpha coefficients for upper arm, lower arm, wrist, neck, trunk, and leg were reported as $0.79,0.82,0.78,0.83,0.84$, and 0.86 , respectively.

The standard Strengths and Difficulties Questionnaire (SDQ), was used to measure psychosocial factors [29], and filled out by the parents. The SDQ is a behavioral screening questionnaire with 25 items measuring five behavioral and emotional dimensions in children under the subscales of hyperactivity, emotional problems, conduct problems, peer problems, and prosocial behaviors. The score of prosocial behaviors represented the score of strengths, while the sum of score of other items constituted the score of difficulties. The parents were requested to choose from "not true", "somewhat true", and "certainly true" to answer each question, with a range of scores from 0 to 2 . Every subscale consisted of five questions and the range of score of strengths was $0-10$ and for that of difficulties was 0-40. Given the score, each subscale was divided into three classes of normal, borderline, and abnormal. Reliability and validity of the questionnaire in Iran has been confirmed by Tehranidost et al. [30].

The prevalence of neck and shoulder pain was evaluated by preshaded manikin pictures in order to show the desired areas. The question was as follows " Have you ever experienced any pain or discomfort in desired areas for one day or more over the past month?" followed by the response (yes/no) [11, 23]. Regarding the severity of pain, the Visual Analog Scale (VAS) was used with a range of $0-10$ with 0 representing no pain and 10 indicating maximum pain [31].

Finally, the students' weight and their backpacks weight were measured using an electronic digital scale (Beurer, Germany) with a $100 \mathrm{~g}$ accuracy. The students' height was measured in centimeters and using a portable stadiometer. Body Mass Index (BMI) was calculated for each student $(\mathrm{kg} / \mathrm{m} 2)$ and classified according to the WHO growth references (2007) into three categories: underweight $(<5$ th percentile), healthy weight ( $\geq 5$ th to $<85$ th percentiles), 
extra weight (including overweight and obese) ( $\geq 85$ th percentile) [32].

All questionnaires were completed through interviewing and by the principal investigator. The students' posture was examined by an observer specialized in ergonomics.

Data was analyzed via the SPSS software v.23. The relationship between the shoulder and neck pain, and the study variables was analyzed by the unadjusted (univariate) logistic regression, and those factors independently associated with the shoulder and neck pain were assessed using the adjusted (multivariate) logistic regression. The effect size was calculated using the chance ratio with a confidence interval of $95 \%$, and a significance level less than 0.05 .

\section{Results}

A total of $32.3 \%$ (224) students had at least one of the neck and shoulder pain problems, and 17.2\% (119 individuals) reported pain in both regions. The presence of neck and shoulder pain was $35.8 \%(n=248)$ and $30.9 \%$ $(n=214)$, respectively. Further, the mean and standard deviation of severity of pain in neck and shoulder areas were reported as $1.36 \pm 0.48$ and $1.31 \pm 0.46$, respectively (with a range of $0-10$ ).

\section{Demographic factors and physical activity/leisure time}

The mean ( \pm standard deviation) of the demographic variables among students were $9.70( \pm 1.61)$ years for the age, $35.88( \pm 16.85) \mathrm{kg}$ for the weight, $136( \pm 16.32) \mathrm{cm}$ for the height, $3.69( \pm 0.74) \mathrm{kg}$ for the backpack weight and $17.68( \pm 3.57) \mathrm{kg} / \mathrm{m} 2$ for the BMI.

According to Table 1, the boys reported significantly less shoulder pain than the girls $(\mathrm{OR}=0.69,95 \% \mathrm{CI}$ : $0.50-0.96 ; p<0.030$ ). Also the use of cell phone/tablet for $1-3 \mathrm{~h}$ per day was significantly associated with neck pain $(\mathrm{OR}=2.11,95 \%$ CI: $1.08-4.13 ; p<0.029)$.

\section{Factors associated with school and curricula}

Table 2 shows the relationship between schoolassociated factors, and neck and shoulder pain. Factors associated with neck pain in the unadjusted (univariate) analysis were very high, seat height $(\mathrm{OR}=2.76,95 \% \mathrm{CI}$ : $1.78-4.29 ; p<0.001)$, very short seat height $(\mathrm{OR}=2.34$, 95\% CI: $1.35-4.06 ; p<0.002)$, very high desk height $(\mathrm{OR}=2.64,95 \% \mathrm{CI}: 1.61-4.32 ; p<0.001)$, very short desk height $(\mathrm{OR}=1.96,95 \% \mathrm{CI}: 1.30-2.96 ; p<0.001)$, too backward seat pan inclination $(\mathrm{OR}=1.51,95 \% \mathrm{CI}$ : $1.03-$ 2.23; $p<0.033)$, too forward seat pan inclination ( $\mathrm{OR}=$ 2.04, 95\% CI: 1.05-3.98; $p<0.035)$, difficulty in viewing the classroom board $(\mathrm{OR}=2.34,95 \% \mathrm{CI}: 1.08-5.04 ; p<$ $0.030)$ and too much homework $(\mathrm{OR}=2.19,95 \% \mathrm{CI}$ : $1.32-3.62 ; p<0.002)$. The students who did their homework on desk and seats $(\mathrm{OR}=0.63,95 \%$ CI: $0.43-0.92$; $p<0.018)$ and laying position at home $(\mathrm{OR}=0.54,95 \%$ CI: $0.37-0.79 ; p<0.002)$ reported less neck pain.

Unadjusted (univariate) analysis indicated that shoulder pain was significantly associated with very high seat height $(\mathrm{OR}=1.56,95 \% \mathrm{CI}: 1.02-2.38 ; p<0.037)$, too backward seat backrest inclination $(\mathrm{OR}=2.07,95 \% \mathrm{CI}$ : $1.20-3.55 ; P<0.008)$, too forward seat backrest inclination $(\mathrm{OR}=1.92,95 \% \mathrm{CI}: 1.06-3.48 ; p<0.030)$, too curved seat backrest curvature $(\mathrm{OR}=1.44,95 \% \mathrm{CI}$ : $1.01-$ 2.04; $p<0.039)$, very high desk height $(\mathrm{OR}=1.62$, 95\% CI: $1.06-2.47 ; p<0.024)$, very short desk height $(\mathrm{OR}=$ 2.50, 95\% CI: $1.51-4.14 ; p<0.001)$ and too much homework $(\mathrm{OR}=2.17,95 \% \mathrm{CI}: 1.27-3.70 ; p<0.004)$.

\section{Psychosocial factors}

Table 3 presents the relationship between psychosocial factors and prevalence of neck and shoulder pain. No statistically significant difference was found between neck pain and psychosocial factors. However, only borderline peers' problems $(\mathrm{OR}=1.56,95 \% \mathrm{CI}: 1.02-2.40 ; p<0.039)$ had a significant relationship with shoulder pain.

\section{RULA score and prevalence of neck and shoulder pain}

Table 4 shows the relationship between RULA score and prevalence of neck and shoulder pain. RULA score level III $(\mathrm{OR}=2.15,95 \%$ CI: $1.29-3.61 ; p<0.003)$, RULA score level IV (OR $=2.64,95 \%$ CI: $1.53-4.56 ; p<0.001)$, and neck pain, as well as RULA at level III $(\mathrm{OR}=1.72$, 95\% CI: $1.02-2.89 ; p<0.039)$, and RULA at level IV $(\mathrm{OR}=1.83$, 95\% CI: $1.06-3.18 ; p<0.030)$ had statistically significant relationships with shoulder pain.

According to the adjusted (multivariate) regression analysis (Table 5), factors with direct association with neck pain were very high desk height $(\mathrm{OR}=1.96,95 \% \mathrm{CI}$ : 1.02 3.74; $p<0.001)$, backward seat pan inclination $(\mathrm{OR}=2.10$, 95\% CI: 1.37-3.24; $\mathrm{p}<0.001)$, forward seat pan inclination $(\mathrm{OR}=3.12$, 95\% CI: $1.46-6.68 ; P<0.003)$, difficulty in viewing the classroom board ( $\mathrm{OR}=2.54,95 \% \mathrm{CI}: 1.10-5.84 ; p<$ 0.028 ), too much homework ( $\mathrm{OR}=2.59,95 \% \mathrm{CI}$ : $1.49-4.51$; $p<0.001)$, RULA score level III ( $\mathrm{OR}=2.88,95 \%$ CI: $1.64-$ 5.05; $\mathrm{p}<0.001)$ and RULA score level IV (OR $=3.12,95 \%$ CI: $1.72-5.63 ; p<0.001)$. The students who did performed their homework on desk and $(\mathrm{OR}=0.59,95 \% \mathrm{CI}$ : 0.39 $0.91 ; p<0.017)$ and in a laying position $(\mathrm{OR}=0.53,95 \% \mathrm{CI}$ : $0.34-0.81 ; p<0.004)$ reported less pain.

According to adjusted (multivariate) regression analysis (Table 6), factors independently related to shoulder pain were very short desk height $(\mathrm{OR}=2.41,95 \% \mathrm{CI}$ : $1.26-4.61 ; p<0.008)$ and too much homework (OR $=$ 1.94, 95\% CI: $1.10-3.42 ; p<0.022)$.

\section{Discussion}

This study investigated the prevalence of neck and shoulder pain among 7-12 years old students. More than 
Table 1 Demographic and Physical/leisure activity factors and risk of neck and shoulder pain in unadjusted (univariate) logistic regression analysis

\begin{tabular}{|c|c|c|c|c|c|c|}
\hline \multirow[t]{2}{*}{ Neck pain } & \multirow[b]{2}{*}{$\%$} & \multirow[b]{2}{*}{ OR $(95 \% \mathrm{Cl})$} & \multirow[b]{2}{*}{$P$ value } & \multicolumn{2}{|c|}{ Shoulder pain } & \multirow[b]{2}{*}{$P$ value } \\
\hline & & & & $\%$ & OR $(95 \% \mathrm{Cl})$ & \\
\hline \multicolumn{7}{|l|}{ Age (year) } \\
\hline$<10$ & 38.2 & Referent & - & 29.1 & Referent & - \\
\hline$\geq 10$ & 33.9 & $1.20(0.88-1.64)$ & 0.237 & 32.3 & $0.86(0.62-1.93)$ & 0.370 \\
\hline \multicolumn{7}{|l|}{ Gender } \\
\hline Boys & 33.3 & Referent & - & 26.7 & Referent & - \\
\hline Girls & 37.9 & $0.82(0.60-1.12)$ & 0.215 & 34.3 & $0.69(0.50-0.96)$ & $0.030^{*}$ \\
\hline \multicolumn{7}{|l|}{ BMI (kg/m2) } \\
\hline healthy weight ( $\geq 5$ th to $<85$ th percentile) & 36.2 & Referent & - & 28.9 & Referent & - \\
\hline under weight (<5th percentile) & 31.9 & $0.82(0.43-1.57)$ & 0.561 & 31.9 & $1.15(0.60-2.19)$ & 0.666 \\
\hline extra weight ( $\geq 85$ th percentile) & 35.8 & $0.98(0.68-1.40)$ & 0.918 & 35.8 & $1.36(0.95-1.97)$ & 0.092 \\
\hline \multicolumn{7}{|l|}{ Hours per week playing sport (h) } \\
\hline$<1$ & 39.7 & Referent & - & 27.2 & Referent & - \\
\hline $1-3$ & 34.9 & $1.30(0.77-2.18)$ & 0.342 & 32 & $0.80(0.46-1.38)$ & 0.429 \\
\hline$>3$ & 33.7 & $1.05(0.67-1.66)$ & 0.806 & 31.7 & $1.01(0.63-1.60)$ & 0.963 \\
\hline \multicolumn{7}{|l|}{ Hours per day using a cell phone/tablet (h) } \\
\hline$<1$ & 22.1 & Referent & - & 30.9 & Referent & - \\
\hline $1-3$ & 35.4 & $2.11(1.08-4.13)$ & $0.029^{*}$ & 28.6 & $0.70(0.39-1.26)$ & 0.239 \\
\hline$>3$ & 37.6 & $1.92(0.95-3.87)$ & 0.068 & 38.9 & $2.12(0.33-1.17)$ & 0.148 \\
\hline \multicolumn{7}{|l|}{ Hours per day using a computer (h) } \\
\hline$<1$ & 36 & Referent & - & 31 & Referent & - \\
\hline $1-3$ & 35.6 & $1.40(0.43-4.52)$ & 0.570 & 28.8 & $0.80(0.26-2.44)$ & 0.705 \\
\hline$>3$ & 28.6 & $1.38(0.38-4.95)$ & 0.620 & 35.7 & $0.72(0.23-2.49)$ & 0.614 \\
\hline \multicolumn{7}{|l|}{ Hours per day playing games (h)- } \\
\hline$<1$ & 35.9 & Referent & 0.305 & 30.7 & Referent & 0.761 \\
\hline $1-3$ & 38.8 & $1.54(0.67-3.52)$ & 0.250 & 31.3 & $0.88(0.40-1.93)$ & 0.846 \\
\hline$>3$ & 26.7 & $1.74(0.67-4.49)$ & & 33.3 & $0.91(0.36-2.28)$ & \\
\hline \multicolumn{7}{|l|}{ Hours per day watching TV (h) } \\
\hline$<1$ & 38.8 & Referent & - & 29.1 & Referent & - \\
\hline $1-3$ & 35 & $1.22(0.82-1.80)$ & 0.320 & 31.3 & $0.86(0.57-1.30)$ & 0.499 \\
\hline$>3$ & 34.2 & $1.03(0.71-1.50)$ & 0.843 & 32.7 & $0.95(0.65-1.39)$ & 0.819 \\
\hline
\end{tabular}

*Statistically significant, -: Not available, Cl Confidence interval, \% Relative frequency, OR Odds Ratio

one-third of students in this study had at least one of shoulder and neck pain problems. Furthermore, physical factors such as school furniture, too much homework, difficulty in viewing the board, and posture (improper sitting positions) were associated with the pain.

Neck pain was associated with very high desk height, as well as forward and backward seat pan inclination. On the other hand, shoulder pain was associated with very short desk height.

Improper height of desk and seat often led to abnormal postures as well as prevalence of shoulder and neck pain [10]. High desk height compels students to lift their arms, causing heavier muscular loads, which in turn results in pain and discomfort in shoulder and neck [33]. Short desk height encourages the back part of the body to lean to a forward position, and thus under load, which could be a possible contributing factor to the pain $[34,35]$. Two studies performed in Hamadan (a city in Iran) confirm the mismatch between the anthropometric dimensions of the students and the furniture. The studies found that, the use of same sized furniture in the elementary schools of Hamadan for all educational grades has increased the mismatch with the students' anthropometric dimensions [36, 37]. Therefore, ergonomic interventions with the aim of improving physical factors in the school environment (designing suitable furniture) may help preventing of such complaints [38-41]. 
Table 2 School-related factors and risk of neck and shoulder pain in unadjusted (univariate) logistic regression analysis

\begin{tabular}{|c|c|c|c|c|c|c|}
\hline \multicolumn{4}{|l|}{ Neck pain } & \multicolumn{3}{|c|}{ Shoulder pain } \\
\hline & $\%$ & OR $(95 \% \mathrm{Cl})$ & $P$ value & $\%$ & OR $(95 \% \mathrm{Cl})$ & $P$ value \\
\hline \multicolumn{7}{|c|}{ Classroom furniture/layout design } \\
\hline \multicolumn{7}{|l|}{ Seat height } \\
\hline Just right & 20.1 & Referent & - & 24 & Referent & - \\
\hline Too high & 37.2 & $2.76(1.78-4.29)$ & $0.001^{*}$ & 31.9 & $1.56(1.02-2.38)$ & $0.037^{*}$ \\
\hline Too low & 41.1 & $2.34(1.35-4.06)$ & $0.002^{*}$ & 33.1 & $1.47(0.86-2.54)$ & 0.157 \\
\hline \multicolumn{7}{|c|}{ Seat backrest height } \\
\hline Just right & 35.1 & Referent & - & 29.4 & Referent & - \\
\hline Too high & 36.4 & $1.05(0.74-1.49)$ & 0.753 & 29.8 & $0.84(0.59-1.20)$ & 0.352 \\
\hline Too low & 35 & $1.06(0.67-1.66)$ & 0.792 & 33.1 & $0.85(0.53-1.36)$ & 0.516 \\
\hline \multicolumn{7}{|c|}{ Seat backrest inclination } \\
\hline Just right & 36.4 & Referent & - & 19.4 & Referent & - \\
\hline Too backward & 37.8 & $1.53(0.94-2.49)$ & 0.084 & 31.7 & $2.07(1.20-3.55)$ & $0.008^{*}$ \\
\hline Too forward & 27.6 & $1.59(0.93-2.72)$ & 0.087 & 33.3 & $1.92(1.06-3.48)$ & $0.030^{*}$ \\
\hline \multicolumn{7}{|c|}{ Seat backrest curvature } \\
\hline Just right & 36.7 & Referent & - & 27.2 & Referent & - \\
\hline Too curved & 41 & $1.12(0.80-1.57)$ & 0.502 & 34.6 & $1.44(1.01-2.04)$ & $0.039^{*}$ \\
\hline Too flat & 34.1 & $1.34(0.81-2.21)$ & 0.243 & 35.1 & $1.41(0.84-2.37)$ & 0.192 \\
\hline \multicolumn{7}{|l|}{ Seat depth } \\
\hline Just right & 34.7 & Referent & - & 30.7 & Referent & - \\
\hline Too deep & 43.5 & $0.97(0.70-1.35)$ & 0.892 & 34.8 & $1.02(0.72-1.43)$ & 0.909 \\
\hline Too narrow & 35.2 & $1.41(0.83-2.40)$ & 0.196 & 30.2 & $1.23(0.71-2.13)$ & 0.460 \\
\hline \multicolumn{7}{|l|}{ Seat width } \\
\hline Just right & 35.5 & Referent & - & 31.1 & Referent & - \\
\hline Too deep & 31 & $0.86(0.58-1.25)$ & 0.437 & 25.4 & $0.92(0.62-1.36)$ & 0.685 \\
\hline Too narrow & 39 & $0.70(0.38-1.28)$ & 0.248 & 32.9 & $0.69(0.36-1.36)$ & 0.260 \\
\hline \multicolumn{7}{|l|}{ Desk height } \\
\hline Just right & 23.7 & Referent & - & 21.9 & Referent & - \\
\hline Too high & 37.9 & $2.64(1.61-4.32)$ & $0.001^{*}$ & 41.2 & $1.62(1.06-2.47)$ & $0.024^{*}$ \\
\hline Too low & 45 & $1.96(1.30-2.96)$ & $0.001^{*}$ & 31.3 & $2.50(1.51-4.14)$ & $0.001^{*}$ \\
\hline \multicolumn{7}{|c|}{ Seat pan inclination } \\
\hline Just right & 28.3 & Referent & - & 31 & Referent & - \\
\hline Too backward & 44.7 & $1.51(1.03-2.23)$ & $0.033^{*}$ & 31.9 & $1.04(0.71-1.53)$ & 0.825 \\
\hline Too forward & 37.5 & $2.04(1.05-3.98)$ & $0.035^{*}$ & 30.1 & $1.08(0.54-2.18)$ & 0.814 \\
\hline \multicolumn{7}{|c|}{ Seat-to-(black) board distance } \\
\hline Just right & 33.7 & Referent & - & 30.1 & Referent & - \\
\hline Too near & 39.4 & $0.98(0.58-1.66)$ & 0.958 & 30.3 & $086(0.49-1.49)$ & 0.592 \\
\hline Too far & 39.7 & $0.77(0.52-1.13)$ & 0.186 & 33.6 & $0.85(0.57-1.27)$ & 0.437 \\
\hline \multicolumn{7}{|c|}{ Classroom teacher placement } \\
\hline Just right & 37.6 & Referent & - & 32.6 & Referent & - \\
\hline Too near & 29.9 & $0.95(0.49-1.85)$ & 0.890 & 26.9 & $1.08(0.54-1.17)$ & 0.811 \\
\hline Too far & 30.8 & $1.35(0.86-2.11)$ & 0.189 & 25.2 & $1.43(0.89-2.29)$ & 0.138 \\
\hline \multicolumn{7}{|c|}{ Viewing the (black) board } \\
\hline Very easy & 24.5 & Referent & - & 31.9 & Referent & - \\
\hline
\end{tabular}


Table 2 School-related factors and risk of neck and shoulder pain in unadjusted (univariate) logistic regression analysis (Continued)

\begin{tabular}{|c|c|c|c|c|c|c|}
\hline \multicolumn{4}{|l|}{ Neck pain } & \multicolumn{3}{|c|}{ Shoulder pain } \\
\hline & $\%$ & OR $(95 \% \mathrm{Cl})$ & $P$ value & $\%$ & OR $(95 \% \mathrm{Cl})$ & $P$ value \\
\hline Neutral & 43.2 & $1.69(0.86-3.33)$ & 0.124 & 27.4 & $1.29(0.67-2.50)$ & 0.441 \\
\hline Very difficult & 35.5 & $2.34(1.08-5.04)$ & $0.030^{*}$ & 26.5 & $1.04(0.47-2.27)$ & 0.951 \\
\hline \multicolumn{7}{|l|}{ Hear the teacher's voice } \\
\hline Very easy & 36.1 & Referent & - & 31 & Referent & - \\
\hline Neutral & 30.8 & $0.79(0.24-2.52)$ & 0.691 & 32.7 & $2.24(0.48-1.35)$ & 0.299 \\
\hline Very difficult & 41.7 & $0.62(0.17-2.60)$ & 0.471 & 16.7 & $2.42(0.47-1.33)$ & 0.285 \\
\hline \multicolumn{7}{|l|}{ Viewing the book/notebook } \\
\hline Very easy & 35.5 & Referent & - & 30.5 & Referent & - \\
\hline Neutral & 37.9 & $0.68(018-2.58)$ & 0.578 & 32.8 & $0.54(0.14-2.06)$ & 0.225 \\
\hline Very difficult & 44.4 & $0.76(0.18-3.15)$ & 0.710 & 44.4 & $0.60(0.14-2.53)$ & 0.365 \\
\hline \multicolumn{7}{|l|}{ Homework } \\
\hline Just right & 26.7 & Referent & - & 22.2 & Referent & - \\
\hline Not enough & 18.8 & $0.63(0.34-1.16)$ & 0.145 & 16.5 & $0.69(0.36-1.31)$ & 0.257 \\
\hline Too much & 44.3 & $2.19(1.32-3.62)$ & $0.002^{*}$ & 38.3 & $2.17(1.27-3.70)$ & $0.004^{*}$ \\
\hline \multicolumn{7}{|l|}{ Position doing homework at home } \\
\hline Sitting on the floor & 33.3 & Referent & - & 32.5 & Referent & - \\
\hline Sitting on the table and the chair & 30 & $0.63(0.43-0.92)$ & $0.018^{*}$ & 29.6 & $1.09(0.73-1.61)$ & 0.661 \\
\hline Lying on the floor & 44.1 & $0.54(0.37-0.79)$ & $0.002^{*}$ & 30.6 & $0.95(0.64-1.42)$ & 0.823 \\
\hline \multicolumn{7}{|l|}{ Schoolbag carriage variables } \\
\hline \multicolumn{7}{|l|}{ Type of school bag } \\
\hline Backpack & 35.9 & Referent & - & 31.4 & Referent & - \\
\hline Other (shoulder bag/wheeled) & 29.4 & $1.34(0.46-3.86)$ & 0.580 & 11.8 & $3.42(0.77-15.11)$ & 0.104 \\
\hline \multicolumn{7}{|l|}{ School bag weight as \% BW } \\
\hline$\leq 10$ & 33.5 & Referent & - & 30.4 & Referent & - \\
\hline$>10$ & 37.2 & $0.84(0.61-1.17)$ & 0.318 & 31.2 & $0.96(0.69-1.34)$ & 0.837 \\
\hline \multicolumn{7}{|c|}{ Time spent carrying school bag (min/day) } \\
\hline$\geq 20$ & 36.3 & Referent & - & 29.2 & Referent & - \\
\hline$>20$ & 33.8 & $11.1(0.74-1.65)$ & 0.602 & 36.8 & $0.71(0.48-1.06)$ & 0.099 \\
\hline \multicolumn{7}{|l|}{ Method of school bag carriage } \\
\hline Both shoulders & 34.2 & Referent & - & 30.6 & Referent & - \\
\hline One shoulders & 44.2 & $1.06(0.39-2.86)$ & 0.909 & 38.4 & $1.41(0.88-2.26)$ & 0.147 \\
\hline Other (by hands/wheels) & 33.3 & $1.58(0.54-4.60)$ & 0.399 & 5.6 & $0.13(0.01-1.01)$ & 0.051 \\
\hline \multicolumn{7}{|l|}{ Method of travel to/from school } \\
\hline Car & 33 & Referent & - & 30.3 & Referent & - \\
\hline Walk & 35.4 & $0.58(0.32-0.95)$ & $0.032^{*}$ & 29.7 & $0.71(0.43-1.20)$ & 0.207 \\
\hline Other & 45.9 & $0.64(0.40-1.04)$ & 0.076 & 37.6 & $0.69(0.42-1.14)$ & 0.157 \\
\hline
\end{tabular}

*Statistically significant, -: Not available, Cl Confidence interval, \% Relative frequency, OR Odds Ratio

In the present study, the amount of homework was significantly associated with shoulder and neck pain, that is, the students who spent a lot of time on doing homework had more shoulder and neck pains. This finding was in line with the findings of the study by Dianat et al. [11]. However, the students who did their homework on desk and seat or in a laying position reported less pain.
It is believed that the worst method of doing homework is bending on the floor [42]. In this position of studying, the spinal cord is bent for a long time which causes extension and muscle weakness in the spinal cord. Furthermore, with a reduction of abductor muscles of the upper part of the body and shoulder due to different reasons in sitting and standing positions for a long time, the extent 
Table 3 Psychosocial factors and risk of neck and shoulder pain in unadjusted (univariate) logistic regression analysis

\begin{tabular}{|c|c|c|c|c|c|c|}
\hline \multicolumn{4}{|l|}{ Neck pain } & \multicolumn{3}{|c|}{ Shoulder pain } \\
\hline & $\%$ & OR $(95 \% \mathrm{Cl})$ & $P$ value & $\%$ & OR $(95 \% \mathrm{Cl})$ & $P$ value \\
\hline \multicolumn{7}{|l|}{ Strengths } \\
\hline \multicolumn{7}{|c|}{ Prosocial behavior } \\
\hline Normal & 36.2 & Referent & & 30.5 & Referent & \\
\hline Borderline & 20.8 & $0.46(0.17-1.25)$ & 0.132 & 41.7 & $1.62(0.71-3.72)$ & 0.251 \\
\hline Abnormal & 42.9 & $1.32(0.45-3.85)$ & 0.609 & 28.6 & $0.91(0.28-2.93)$ & 0.875 \\
\hline \multicolumn{7}{|l|}{ Difficulties } \\
\hline \multicolumn{7}{|c|}{ Emotional symptoms } \\
\hline Normal & 34.4 & Referent & & 30.9 & Referent & \\
\hline Borderline & 38.6 & $1.20(0.68-2.10)$ & 0.525 & 29.8 & $0.95(0.52-1.72)$ & 0.871 \\
\hline Abnormal & 40.5 & $1.30(0.86-1.95)$ & 0.206 & 31.4 & $1.02(0.66-1.57)$ & 0.909 \\
\hline \multicolumn{7}{|c|}{ Conduct problems } \\
\hline Normal & 33.7 & Referent & & 30.4 & Referent & \\
\hline Borderline & 40.6 & $1.34(0.86-2.11)$ & 0.193 & 35.4 & $1.25(0.79-1.99)$ & 0.329 \\
\hline Abnormal & 40.5 & $1.34(0.88-2.03)$ & 0.167 & 29.3 & $0.95(0.61-1.48)$ & 0.826 \\
\hline \multicolumn{7}{|l|}{ Hyperactivity } \\
\hline Normal & 35.2 & Referent & & 30.6 & Referent & \\
\hline Borderline & 37.1 & $1.08(0.64-1.82)$ & 0.747 & 34.3 & $1.18(0.69-2.00)$ & 0.531 \\
\hline Abnormal & 38 & $1.12(0.72-1.75)$ & 0.590 & 30.3 & $0.97(0.61-1.55)$ & 0.906 \\
\hline \multicolumn{7}{|c|}{ Peer problems } \\
\hline Normal & 34.2 & Referent & & 23.7 & Referent & \\
\hline Borderline & 33.3 & $1.14(0.77-1.69)$ & 0.504 & 33.3 & $1.56(1.02-2.40)$ & $0.039^{*}$ \\
\hline Abnormal & 37.3 & $0.96(0.59-1.55)$ & 0.873 & 32.7 & $1.61(0.96-2.68)$ & 0.067 \\
\hline \multicolumn{7}{|c|}{ Total difficulties } \\
\hline Normal & 31.7 & Referent & & 30.8 & Referent & \\
\hline Borderline & 24.6 & $1.28(0.82-1.99)$ & 0.274 & 32.3 & $1.07(0.67-1.70)$ & 0.758 \\
\hline Abnormal & 48.4 & $1.10(0.71-1.71)$ & 0.661 & 30.1 & $0.96(0.61-1.54)$ & 0.969 \\
\hline
\end{tabular}

*Statistically significant, -: Not available, Cl Confidence interval, \% Relative frequency, OR Odds Ratio

of kyphosis curve increases [43, 44]. The abductor muscles are needed to produce the force required to hold the vertebral column straight. By decreasing the ability of these muscles to generate force, the spinal column does not have sufficient support for the abductor muscles to keep it straight in standing and sitting postures. As a result, the weight and force of the upper part of the trunk are placed on the inactive limbs of the ligaments, bones and articular cartilage, etc. This weight can increase the length of the abductor muscles, thus affecting the arches of the vertebral column and increasing the kyphosis arc [45]. Doing homework in a bending position on the floor increases the

Table 4 RULA score and risk of neck and shoulder pain in unadjusted (univariate) logistic regression analysis

\begin{tabular}{|c|c|c|c|c|c|c|}
\hline \multicolumn{4}{|l|}{ Neck pain } & \multicolumn{3}{|c|}{ Shoulder pain } \\
\hline & $\%$ & OR $(95 \% \mathrm{Cl})$ & $P$ value & $\%$ & OR $(95 \% \mathrm{Cl})$ & $P$ value \\
\hline \multicolumn{7}{|l|}{ RULA } \\
\hline Level 1 & 16.1 & Referent & & 14.3 & Referent & \\
\hline Level 2 & 40.9 & $0.59(0.30-1.18)$ & 0.140 & 35.5 & $0.52(0.25-1.05)$ & 0.068 \\
\hline Level 3 & 45.9 & $2.15(1.29-3.61)$ & $0.003^{*}$ & 37 & $1.72(1.02-2.89)$ & $0.039^{*}$ \\
\hline Level 4 & 24.2 & $2.64(1.53-4.56)$ & $0.001^{*}$ & 24.2 & $1.83(1.06-3.18)$ & $0.030^{*}$ \\
\hline
\end{tabular}

*Statistically significant, -: Not available, CI Confidence interval, \% Relative frequency, OR Odds Ratio 
Table 5 Factors associated with neck pain in adjusted (multivariate) logistic regression analysis

\begin{tabular}{|c|c|c|}
\hline \multicolumn{3}{|l|}{ Neck pain } \\
\hline & $\mathrm{R}(95 \% \mathrm{Cl})$ & $P$ value \\
\hline \multicolumn{3}{|l|}{ School-related factors } \\
\hline \multicolumn{3}{|l|}{ Desk height } \\
\hline Just right & Referent & \\
\hline Too high & $1.96(1.02-3.74)$ & $0.042^{*}$ \\
\hline Too low & $1.01(0.58-1.73)$ & 0.976 \\
\hline \multicolumn{3}{|l|}{ Seat pan inclination } \\
\hline Just right & Referent & \\
\hline Too backward & $2.10(1.37-3.24)$ & $0.001^{*}$ \\
\hline Too forward & $3.12(1.46-6.68)$ & $0.003^{*}$ \\
\hline \multicolumn{3}{|l|}{ Viewing the (black) board } \\
\hline Very easy & Referent & \\
\hline Neutral & $1.87(0.96-3.63)$ & 0.062 \\
\hline Very difficult & $2.54(1.10-5.84)$ & $0.028^{*}$ \\
\hline \multicolumn{3}{|l|}{ Homework } \\
\hline Just right & Referent & \\
\hline Not enough & $0.89(0.46-1.72)$ & 0.740 \\
\hline Too much & $2.59(1.49-4.51)$ & $0.001^{*}$ \\
\hline \multicolumn{3}{|l|}{ Position doing homework at home } \\
\hline Sitting on the floor & Referent & \\
\hline Sitting on the table and the chair & $0.59(0.39-0.91)$ & $0.017^{*}$ \\
\hline Lying on the floor & $0.53(0.34-0.81)$ & $0.004^{*}$ \\
\hline \multicolumn{3}{|l|}{ RULA } \\
\hline Level 1 & Referent & \\
\hline Level 2 & $0.84(0.40-1.75)$ & 0.655 \\
\hline Level 3 & $2.88(1.64-5.05)$ & $0.001^{*}$ \\
\hline Level 4 & $3.12(1.72-5.63)$ & $0.001^{*}$ \\
\hline
\end{tabular}

*Statistically significant, $\mathrm{Cl}$ Confidence interval, OR Odds Ratio

Table 6 Factors associated with shoulder pain in adjusted (multivariate) logistic regression analysis

\begin{tabular}{lll}
\hline Shoulder pain & & \\
\hline \multicolumn{2}{l}{ OR $(95 \% \mathrm{Cl})$} & $P$ value \\
Deskool-related factors & & \\
Just right & Referent & \\
Too high & $1.21(0.70-2.07)$ & 0.481 \\
Too low & $2.41(1.26-4.61)$ & $0.008^{*}$ \\
Homework & & \\
Just right & Referent & \\
Not enough & $0.82(0.42-1.62)$ & 0.579 \\
Too much & $1.94(1.10-3.42)$ & $0.022^{*}$ \\
\hline
\end{tabular}

*Statistically significant, $\mathrm{Cl}$ Confidence interval, OR Odds Ratio percentage of kyphosis, but the use of desk decreases it $[42,44]$.

Difficulty in viewing the board was one of the physical factors associated with neck pain, which is consistent with the results of Dianat et al's study [11].. It might be attributed to the improper arrangement of desks and seats, unsuitable distance of the blackboard, improper lighting of the class, and other ergonomic principles in the classroom.

RULA score levels III and IV were associated with neck pain in the current study. This supports the findings of a number of previous studies that have reported a significant relationship between bending and rotating of neck and musculoskeletal pains of neck in school age children and adolescents. However, these studies used different instruments (Portable Ergonomic Observation Method/sagittal plane digital photographs) [46-48]. Students usually sit with improper postures as bending their neck, trunk, and back for a long time or rotating them, which in turn causes musculoskeletal pain [47-49]. The poor postures and prolonged sitting are common in the classroom $[50,51]$. In the present study, given the RULA score at levels three and four (investigation and changes are required soon and immediately), education regarding the proper ways of positioning the head and neck to prevent these complaints is recommended [20, 50, 52].

Individual factors such as physical/leisure activity (physical activity time, using cellphone and computer, playing games, watching TV) and BMI were not significantly related to neck and shoulder pain which is in line with other studies conducted by Diepenmaat et al. in Netherland [23] Murphy et al. in England [34] and Dianat et al. in Iran [11].

This study indicated that psychosocial factors in the adjusted (multivariate) regression had no significant relationship with shoulder and neck pain. This stands contrary to the previous research which has reported the relationship between psychosocial factors and musculoskeletal complaints in school age children and adolescents $[8,16,53,54]$. This may result from the social acceptance of the self-report data. Concerning the young age of students, the SDQ questionnaire was completed by their parents as a self-report. By considering the importance of children's health for their parents and also their tendency to report their children's psychosocial conditions desirably, these can have an impact on the study findings.

The response rate in this study was high. Due to the probability of incomplete ability of students to responding the questions, the interview, as the data gathering strategy, was used in this study. Furthermore, to enhance the accuracy of data, posture of students was observed and evaluated by a specialist observer. 
Despite the robust findings, this study has several limitations. This study had a cross-sectional design and the cause-effect relationship between shoulder and neck pain and its risk factors could not be established. Another limitation was using self-report manner for shoulder and neck pain reported by children and their parents. Although other studies also used this procedure of data collection $[55,56]$, the use of a subjective measurement without a physical examination is not sufficient for the assessment of prevalence of neck and shoulder pain. This is the limitation of RULA checklist that does not consider angles of side bending and twisting and also only takes one posture into account for those students who have a high amount of displacement in class.

\section{Conclusion}

The prevalence of neck and shoulder pain was high in the studied population. Unsuitability of school furniture, too much homework, difficulty in viewing the classroom board, and improper sitting positions of students are related to this health problem. Therefore, the proper interventions, considering the risk factors assessed in this study are suggested.

\section{Abbreviations}

BMI: Body Mass Index; Cl: Confidence interval; OR: Odds ratio; RULA: Rapid upper limbs assessment; SDQ: Strengths and difficulties of questionnaire

\section{Acknowledgments}

This study, as a part of PhD thesis, was approved by Hamadan University of Medical Sciences. The authors would like to thank all the students, and their parents who participated in this study.

\section{Authors' contributions}

EG contributed to the conception and design of the study, data collection, data analysis and interpretation, and writing up the manuscript. LT contributed to the design of the study, data analysis and interpretation, and critical revision of the manuscript. ID, $\mathrm{RH}$ and AK contributed to the design of the study and critical revision of the manuscript. FRS contributed to the conception and design of the study, data analysis and interpretation, and manuscript writing. All authors read and approved the final version of the manuscript.

\section{Funding}

This study support by the Deputy of Research and Technology of Hamadan University of Medical Sciences, financially (NO: 9611177279).

\section{Availability of data and materials}

The datasets used and analyzed during the current study are available from the corresponding author on reasonable request.

\section{Ethics approval and consent to participate}

This study was approved by the Hamadan University of Medical Sciences Ethics Committee (approval code: IR.UMSHA.REC.1396.641); the parents provided written consent to their elementary school-age children's participation in the study.

\section{Consent for publication}

Not applicable.

\section{Competing interests}

The authors declare that they have no competing interest.

\section{Author details}

'Department of Public Health, School of Public Health, Hamadan University of Medical Sciences, Hamadan, Iran. ${ }^{2}$ Department of Occupational Health and Ergonomics, Faculty of Health, Tabriz University of Medical Sciences, Tabriz, Iran. ${ }^{3}$ Department of Ergonomics, School of Public Health, Hamadan University of Medical Sciences, Hamadan, Iran. ${ }^{4}$ Research Center for Health Sciences, Hamadan University of Medical Sciences, Hamadan, Iran.

${ }^{5}$ Department of Biostatistics, School of Public Health Sciences Research Center, Hamadan University of Medical Sciences, Hamadan, Iran. ${ }^{6}$ Modeling of Non-communicable diseases research center, Hamadan University of Medical Sciences, Hamadan, Iran. ${ }^{7}$ Social Determinants of Health Research Center, Hamadan University of Medical Sciences, Hamadan, Iran.

Received: 28 April 2019 Accepted: 30 September 2019

Published online: 16 October 2019

\section{References}

1. Picavet HS, Schouten JS. Musculoskeletal pain in the Netherlands: prevalences, consequences and risk groups, the DMC (3)-study. Pain. 2003; 102:167-78.

2. Fejer R, Kyvik KO, Hartvigsen J. The prevalence of neck pain in the world population: a systematic critical review of the literature. Eur Spine J. 2006; 15(6):834-48.

3. Shan Z, Deng G, Li J, Li Y, Zhang Y, Zhao Q. Correlational analysis of neck/ shoulder pain and low back pain with the use of digital products, physical activity and psychological status among adolescents in Shanghai. PLoS One. 2013;8(10):e78109

4. Scarabottolo CC, Pinto R, Oliveira C, Zanuto E, Cardoso J, Christofaro D. Back and neck pain prevalence and their association with physical inactivity domains in adolescents. Eur Spine J. 2017;26(9):2274-80.

5. Vos T, Barber RM, Bell B, Bertozzi-Villa A, Biryukov S, Bolliger I, et al. Global, regional, and national incidence, prevalence, and years lived with disability for 301 acute and chronic diseases and injuries in 188 countries, 1990-2013: a systematic analysis for the global burden of disease study 2013. Lancet. 2015;386(9995):743-800.

6. Hoy D, Protani M, De R, Buchbinder R. The epidemiology of neck pain. Best Pract Res Clin Rheumatol. 2010;24(6):783-92.

7. Institute for Health Metrics and Evaluation. GBD compare. 2015. http:// vizhub.healthdata.org/gbd-compare/. Accessed 12 Oct 2019.

8. Fares J, Fares MY, Fares Y. Musculoskeletal neck pain in children and adolescents: risk factors and complications. Surg Neurol Int. 2017;8:72.

9. Azabagic S, Spahic R, Pranjic N, Mulic M. Epidemiology of musculoskeletal disorders in primary school children in Bosnia and Herzegovina. Mater Soc. 2016;28(3):164.

10. Shan Z, Deng G, Li J, Li Y, Zhang Y, Zhao Q. How schooling and lifestyle factors effect neck and shoulder pain? A cross-sectional survey of adolescents in China. Spine. 2014;39(4):E276-E83.

11. Dianat I, Alipour A, Asgari JM. Risk factors for neck and shoulder pain among schoolchildren and adolescents. J Paediatr Child Health. 2018;54(1):20-7.

12. Dockrell S, Simms C, Blake C. Schoolbag carriage and schoolbag-related musculoskeletal discomfort among primary school children. Appl Ergon. 2015:51:281-90.

13. Auvinen J, Eskola PJ, Ohtonen H-R, Paananen M, Jokelainen J, Timonen M, et al. Long-term adolescent multi-site musculoskeletal pain is associated with psychological distress and anxiety. J Psychosom Res. 2017;93:28-32.

14. Wirth B, Potthoff T, Rosser S, Humphreys BK, de Bruin ED. Physical risk factors for adolescent neck and mid back pain: a systematic review. Chiropr Man Therap. 2018;26(1):36.

15. De Vitta A. Trize DdM, Fiorelli a, Carnaz L, De Conti MHS, Simeão SFdAP. Neck/shoulders pain and its relation to the use of tv/computer/videogame and physical activity in school students from Bauru. Fisioterapia em Movimento. 2014;27(1):111-8.

16. Prins $Y$, Crous $L$, Louw $Q$. A systematic review of posture and psychosocial factors as contributors to upper quadrant musculoskeletal pain in children and adolescents. Physiother Theory Pract. 2008;24(4):221-42.

17. Brink Y, Louw QA. A systematic review of the relationship between sitting and upper quadrant musculoskeletal pain in children and adolescents. Man Ther. 2013;18(4):281-8.

18. Hakala P, Rimpelä A, Salminen JJ, Virtanen SM, Rimpelä M. Back, neck, and shoulder pain in Finnish adolescents: national cross sectional surveys. BMJ. 2002;325(7367):743. 
19. Siivola SM, Levoska S, Latvala K, Hoskio E, Vanharanta H, KeinänenKiukaanniemi S. Predictive factors for neck and shoulder pain: a longitudinal study in young adults. Spine. 2004;29(15):1662-9.

20. Koh MJ, Park SY, Park EJ, Park SH, Jeon HR, Kim M-G, et al. The effect of education on decreasing the prevalence and severity of neck and shoulder pain: a longitudinal study in Korean male adolescents. Korean J Anesthesiol. 2014;67(3):198-204.

21. Viana MC, Lim CC, Pereira FG, Aguilar-Gaxiola S, Alonso J, Bruffaerts R, et al, Previous mental disorders and subsequent onset of chronic back or neck pain: findings from 19 countries. J Pain. 2018;19(1):99-110.

22. Keeratisiroj $O$, Siritaratiwat W. Prevalence of self-reported musculoskeletal pain symptoms among school-age adolescents: age and sex differences. Scand J Pain. 2018;18(2):273-80.

23. Diepenmaat A, Van der Wal M, De Vet H, Hirasing R. Neck/shoulder, low back, and arm pain in relation to computer use, physical activity, stress, and depression among Dutch adolescents. Pediatrics. 2006;117(2):412-6.

24. Ståhl M, Kautiainen H, El-Metwally A, Häkkinen A, Ylinen J, Salminen JJ, et al. Non-specific neck pain in schoolchildren: prognosis and risk factors for occurrence and persistence. A 4-year follow-up study. Pain. 2008;137(2):316-22.

25. El-Metwally A, Salminen JJ, Auvinen A, Macfarlane G, Mikkelsson M. Risk factors for development of non-specific musculoskeletal pain in preteens and early adolescents: a prospective 1-year follow-up study. BMC Musculoskelet Disord. 2007:8(1):46.

26. Hatami M, Taib MNM, Jamaluddin R, Saad HA, Djazayery A, Chamari M, et al. Dietary factors as the major determinants of overweight and obesity among Iranian adolescents. A cross-sectional study. Appetite. 2014;82:194201.

27. McAtamney L, Corlett EN. RULA: a survey method for the investigation of work-related upper limb disorders. Appl Ergon. 1993;24(2):91-9.

28. Dianat I, Salimi A. Working conditions of Iranian hand-sewn shoe workers and associations with musculoskeletal symptoms. Ergonomics. 2014;57(4): 602-11.

29. Goodman R. The strengths and difficulties questionnaire: a research note. J Child Psychol Psychiatry. 1997;38(5):581-6.

30. Tehrani Dost MSZ, Pakbaz B, Rezaei A, Ahmadi F. Validity of the Persian version of the Strengths and Difficulties Questionnaire. Adv Cogn Sci. 2006;8(4):33-9.

31. Huskisson E. Measurement of pain. J Rheumatol. 1982;9:768-9.

32. World Health Organization. The WHO Child Growth Standards, Indicators, BMI-for-age Girls 5 to 19 years (percentile) and BMI-for-age Boys 5 to 19 years (percentile). 2007. http://www.who.int/childgrowth/standards/en/. Accessed 12 Oct 2019.

33. Dianat I, Karimi MA, Hashemi AA, Bahrampour S. Classroom furniture and anthropometric characteristics of Iranian high school students: proposed dimensions based on anthropometric data. Appl Ergon. 2013:44(1):101-8.

34. Murphy S, Buckle P, Stubbs D. A cross-sectional study of self-reported back and neck pain among English schoolchildren and associated physical and psychological risk factors. Appl Ergon. 2007;38(6):797-804.

35. Salminen J, Pentti J, Terho P. Low back pain and disability in 14-year-old schoolchildren. Acta Paediatr. 1992;81(12):1035-9.

36. Heidarimoghadam R, Golmohammadi R, Roshanaei G, Zare R. Assessing the match between female primary students' anthropometric dimensions and furniture dimensions in Hamadan schools in 2013. Health Saf Work. 2015;5(1):47-56.

37. Heidarimoghadam R, Motamedzade M, Roshanaei G, Ahmadi R. Investigating the match between male primary students' anthropometric dimensions and existing furniture dimensions in Hamadan schools in 2013. J Ergonomics. 2014;2(1):9-18.

38. Ismail SA, Tamrin SB, Hashim Z. The association between ergonomic risk factors, rula score, and musculoskeletal pain among school children: a preliminary result. Global J Health Sci. 2009;1(2):73.

39. Mandal A. The prevention of back pain in school children. Hard facts about soft machines; 1994. p. 269-78.

40. Trevelyan F, Legg S. Back pain in school children-where to from here? Appl Ergon. 2006;37(1):45-54

41. Syazwan A, Azhar MM, Anita A, Azizan H, Shaharuddin M, Hanafiah JM, et al. Poor sitting posture and a heavy schoolbag as contributors to musculoskeletal pain in children: an ergonomic school education intervention program. J Pain Res. 2011;4:287.

42. Minoo D, Nasser B, Mahmood S. Prevalence and causes of postural deformities in upper and lower extremities among 9-18 years old school female in Golestan province. Eur J Exp Biol. 2013;3(6):115-21.
43. Hovanlou A, Sadeghi H, Rabieizadeh A. The relationship between trunk strength and flexibility muscles with kyphosis curvature ratio in boy guidance students. J Mov Sci Sports. 2009;7(13):31-41.

44. Quka N, Stratoberdha D, Selenica R. Risk factors of poor posture in children and its prevalence. Acad J Interdiscip Stud. 2015;4(3):97.

45. Briggs AM, Greig AM, Wark JD, Fazzalari NL, Bennell KL. A review of anatomical and mechanical factors affecting vertebral body integrity. Int J Med Sci. 2004;1(3):170

46. Murphy S, Buckle P, Stubbs D. Classroom posture and self-reported back and neck pain in schoolchildren. Appl Ergon. 2004;35(2):113-20.

47. Geldhof E, De Clercq D, De Bourdeaudhuij I, Cardon G. Classroom postures of 8-12 year old children. Ergonomics. 2007;50(10):1571-81.

48. Straker LM, O'Sullivan PB, Smith AJ, Perry MC. Relationships between prolonged neck/shoulder pain and sitting spinal posture in male and female adolescents. Man Ther. 2009;14(3):321-9.

49. Ilbeigi S, Kabootari A, Afzalpour M, Farzaneh $\mathrm{H}$. The relationship between sitting posture and musculoskeletal pain in boy elementary school students. J Ergon. 2018;5(3):41-9.

50. Cardon G, De Clerca D, De Bourdeaudhuij I, Breithecker D. Sitting habits in elementary schoolchildren: a traditional versus a "moving school". Patient Educ Couns. 2004;54(2):133-42.

51. Murphy S, Buckle P, Stubbs D. The use of the portable ergonomic observation method (PEO) to monitor the sitting posture of schoolchildren in the classroom. Appl Ergon. 2002;33(4):365-70.

52. NBd S, Sedrez JA, Candotti CT, Vieira A. Immedlate and follow-up effects of a posture educatlon program for elementary school students. Rev Paul Pediatr. 2017;35(2):199-206.

53. Myrtveit SM, Sivertsen B, Skogen JC, Frostholm L, Stormark KM, Hysing M. Adolescent neck and shoulder pain-the association with depression, physical activity, screen-based activities, and use of health care services. J Adolesc Health. 2014;55(3):366-72.

54. Rees CS, Smith AJ, O'Sullivan PB, Kendall GE, Straker LM. Back and neck pain are related to mental health problems in adolescence. BMC Public Health. 2011;11(1):382.

55. Auvinen JP, Paananen MV, Tammelin TH, Taimela SP, Mutanen PO, Zitting PJ, et al. Musculoskeletal pain combinations in adolescents. Spine. 2009; 34(11):1192-7.

56. Taimela S, Kujala UM, Salminen JJ, Viljanen T. The prevalence of low back pain among children and adolescents: a nationwide, cohort-based questionnaire survey in Finland. Spine. 1997;22(10):1132-6.

\section{Publisher's Note}

Springer Nature remains neutral with regard to jurisdictional claims in published maps and institutional affiliations.

\section{Ready to submit your research? Choose BMC and benefit from:}

- fast, convenient online submission

- thorough peer review by experienced researchers in your field

- rapid publication on acceptance

- support for research data, including large and complex data types

- gold Open Access which fosters wider collaboration and increased citations

- maximum visibility for your research: over 100M website views per year

At BMC, research is always in progress.

Learn more biomedcentral.com/submissions 